\title{
Report of Congenital heart block and Atrial Septal Aneurysm in a case of Neonatal Lupus
}

\author{
Mohinish S*, Sahana Devadas, Mithun Madhav and Anusha PP \\ Department of Pediatrics, Bangalore medical college and research institute, India
}

Submission: January 06, 2020; Published: January 29, 2020

*Corresponding author: Mohinish S, Department of Pediatrics, Bangalore medical college and research institute, Bangalore, Karnataka, India

Abstract

Background: Neonatal lupus erythematosus is an uncommon disease. Congenital complete heart block (CCHB) usually happens in neonates with maternal systemic lupus erythematosus. The most prevalent presentation of CCHB is bradycardia that can be diagnosed through an electrocardiogram.

Case report: Here in, we present the case of a full-term male neonate with gestational age of 37 weeks and birth weight of $2100 \mathrm{~g}$, whose mother had positive anti-Ro/SSA antibodies. The mother was asymptomatic without any criteria of systemic lupus erythematosus. The newborn presented with bradycardia, respiratory distress with structural heart disease. Baby was connected to mechanical ventilator and did not need pacemaker implantation.

Conclusion: The rarity of disease suggests that many components must come together for the full expression of CHB and therapies may have benefit at multiple points along the cascade. Currently, the optimal approach employs serial echocardiograms to identify an early marker, which represents potentially progressive injury but is reversible with treatment.

Keywords: Anti-Ro/SSA Autoantibodies; Arrhythmia; Bradycardia; Congenital complete heart block; Neonatal lupus erythematosus; Atrial septal aneurysm

\section{Introduction}

The congenital complete heart block (CCHB) is a rare disorder with high morbidity and mortality rates. The incidence rate of this disease is reported to range between 1:15,000 and 1:22,000 live births [1]. CCHB is associated with maternal lupus or other autoimmune diseases such as Jorgen's syndrome [2]. CCHB happens with the transplacental passage of maternal anti-Ro/SSA and anti-La/SSB autoantibodies, which affects atrio-ventricular node of fetus and damages the development of cardiac conduction system [3]. The total incidence rate of fetal CCHB through anti-Ro/ La-positive mothers is reported to be about 1-5\%. However, the risk of CCHB occurrence rises up to $25 \%$ for those with previous affected children. Moreover, the risk of CCHB is higher if the mother has a previous child with neonatal lupus erythematosus (NLE) or hypothyroidism due to autoantibodies. The most common clinical manifestations of NLE are related to cutaneous, cardiac, and hepato-biliary abnormalities. Some infants also present with hematologic disorders such as pancytopenia. The co-occurrence of CCHB with structural cardiac abnormalities increases the rate of mortality $[4,5]$. Features of congenital atrio-ventricular block particularly depend on the timing of the presentation and the accompanying structural heart disease. Mothers can be absolutely asymptomatic with positive anti-Ro and anti-La autoantibodies. In this case, incidental findings such as bradycardia or hydrops fetalis are the only clues for further evaluations and diagnosis [6]. Some evidence suggests that administration of steroids and immunoglobulins or plasmapheresis in mothers can reverse the complete heart block in the fetus [7]. In the current study, we present the case of a newborn with isolated CCHB without congenital cardiac disease or other NLE complications. This infant did not require pace-maker implantation.

\section{Case Report}

A 1-day-old full-term male neonate with birth weight of 2300 gram, admitted to Neonatal Intensive Care Unit (NICU) due to bradycardia $(60-70 \mathrm{bpm})$ and respiratory distress (Figure 1). Mother was 20 years old primi with uneventful history. In 30 weeks of gestation, she was referred to the emergency department because of foetal bradycardia (70-80bpm), diagnosed through a 
routine abdominal ultrasound examination. Ultrasound revealed no evidence of foetal distress. Foetal echocardiography showed complete heart block without any structural heart damage and mild pericardial effusion (isolated congenital heart block). She did not present any symptoms of autoimmune disease; she was not evaluated. At 37 weeks of gestation, emergency caesarean section was performed due to severe oligohydramios and foetal bradycardia; the heart rate was $65 \mathrm{bpm}$ at birth. At NICU, the baby was intubated due to respiratory distress and extubated after about 48 hours; Baby was eumorphic, euthermic, euglycemic and hemodynamically stable. 12 lead ECG with normal standardization showed complete heart block. (Figure 2,3)

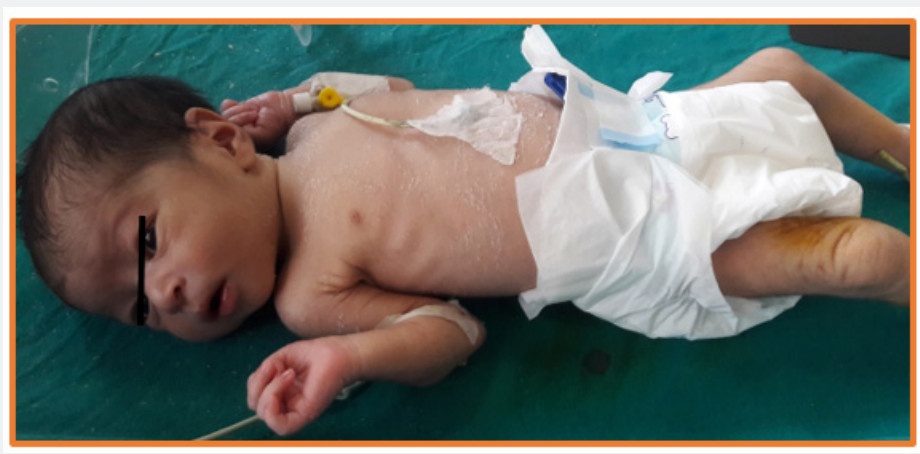

Figure 1: Appearance of baby, no rashes noted.

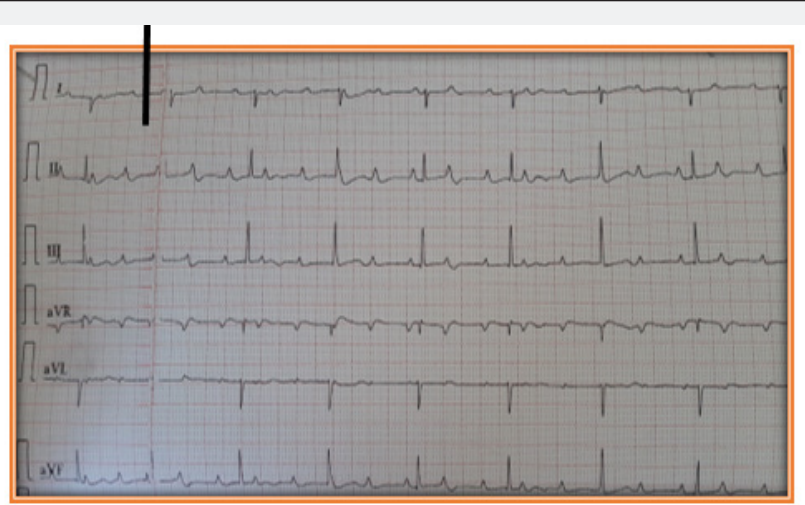

Figure 2: 12 lead ECG showing leads I, II, III, aVR, aVL and aVF revealing complete atrio-ventricular dissociation with atrial rate of 150/min and ventricular rate of $56 / \mathrm{min}$.

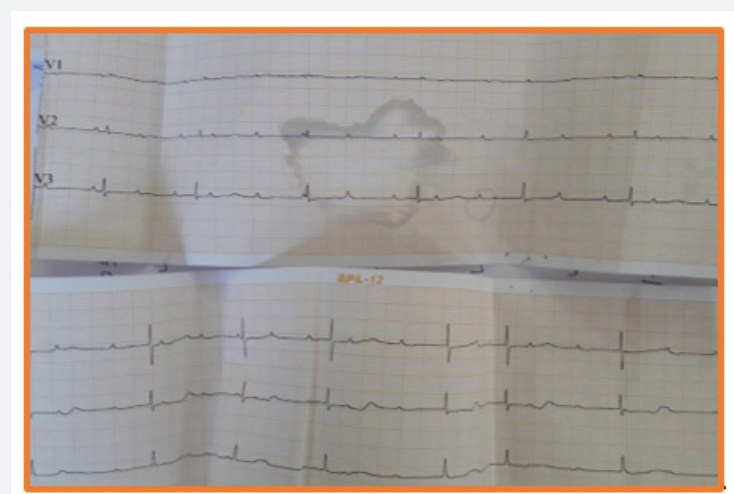

Figure 3: 12 lead ECG shows that each P wave is not preceded by ORS complexes in chest leads, suggesting Heart Block with complete atrio-ventricular dissociation.

Biochemical tests and arterial blood gas evaluation were within the normal range.
2D Echocardiography revealed situs solitus, normal AV and semilunar valves, A-V desynchrony, PDA (1.6mm R-L Shunt) and atrial septal aneurysm (Figure 4). 


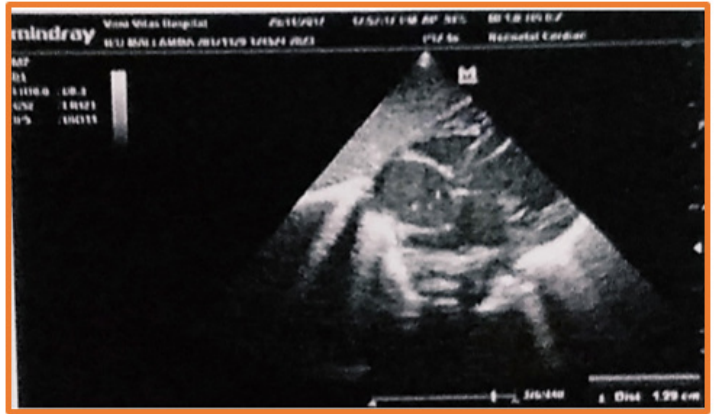

Figure 4: 2D Echo in 4 chamber subcostal view showing Atrial Septal Aneurysm $(0.69 \mathrm{cms})$ projecting into left atrium.

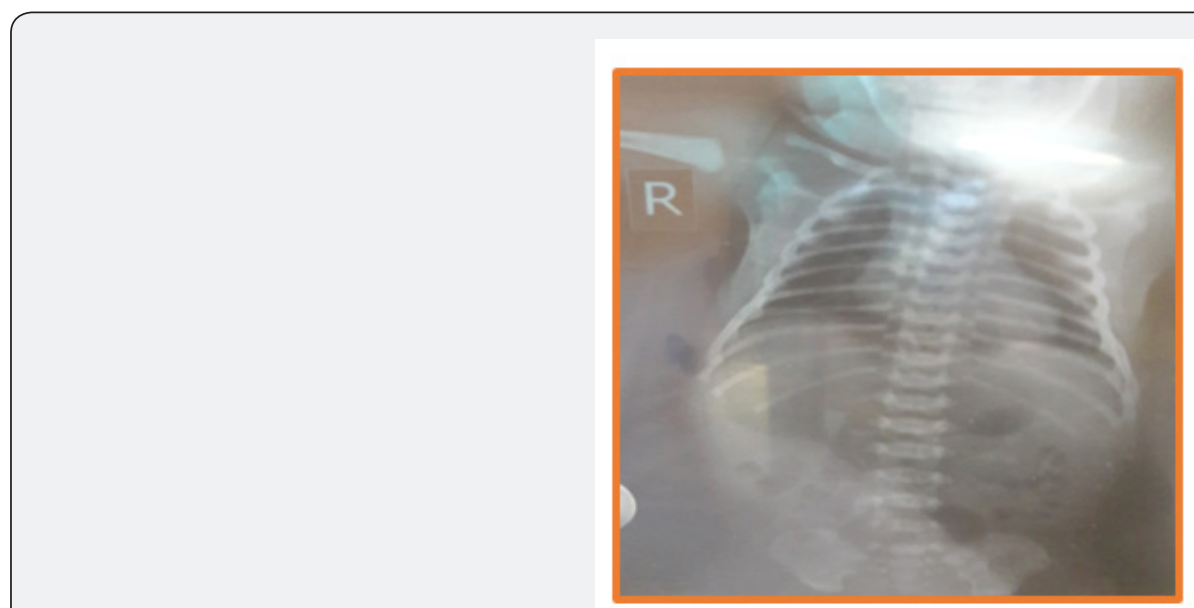

Figure 5: Antero posterior chest X-ray view showing normal heart size. $5)$.

Chest X ray was normal with no cardiomegaly features (Figure

Even though mother did not present with any symptoms of autoimmune disease; however, immunological tests showed positive anti-Ro/SSA. Antibody Ro/SSA was detected by enzyme-linked immunosorbent assay (ELISA) and Western blot immunodiffusion tests. Baby's ANA panel negative. The neonate was carefully followed up for 10 days, and he did not require pacemaker implantation. During 10 days of hospital stay the newborn had good general condition and was breast-fed.

\section{Discussion}

NLE is an uncommon transplacentally acquired autoimmune disorder, which affects atrio-ventricular node and His bundles of fetal heart and can cause cardiac fibrosis and calcification [8]. Fetal exposure to these maternal autoantibodies can cause myocarditis and late-onset cardiomyopathy [9]. Neonatal atrial septum maybe prone to aneurysm formation because of inherent structural weakness [10]. Uncomplicated and isolate ASA is considered to be a benign and transient observation; reports have shown that it could be a cause of fetal atrial arrhythmias (as in this case). It has been suggested that undulating movements of the aneurysm initiate these arrhythmias [11]. Conduction disorders especially with ASA is rare, and when coexisting, the ASA could still run the natural course of resolution at the end of first year of life [12]. In the presence of a co-existing structural cardiac defects or very low heart rate $<55 / \mathrm{min}$, conduction defect will entail surgical insertion of a pacemaker [13]. In the absence of other coexisting cardiac anomaly or very low heart rate, patients with conduction defects could thrive without a pacemaker device in the neonatal and early infancy [14]. The peak onset of the diagnosis of CCHB is between 18 and 24 weeks of gestation, about six weeks after effective placental transport of maternal IgG antibodies [15]. The passage of maternal autoantibodies causes fetal bradycardia, which is detected by fetal echocardiography. Hydrops fetalis, endocardial fibroelastosis, and delivery at less than 32 weeks increase the rate of mortality in patients with CCHB [16]. Despite other manifestations of lupus erythematous syndrome, heart block is not reversible [17]. The degree of heart block in NLE may vary from first degree to third degree block, but most cases diagnosed in utero present with at least second degree or more advanced block [18]. Approximately two- thirds of these patients need pacemaker. On long-term follow-up, babies with cardiac NLE have a risk of developing cardiomyopathy (18\%). Cardiomyopathy can develop despite early institution of permanent pacemaker [19]. Dexamethasone is one of the treatment options during pregnancy 
since it is not metabolized by the placenta [20]. Plasmapheresis and beta-mimetic agents are other treatments for this disorder [21]. In a case series study evaluating 16 patients with isolated CCHB and late-onset cardiomyopathy, the occurrence of lateonset cardiomyopathy was reported to be $5-11 \%$ despite the implantation of pacemaker in the CCHB patients [22]. Diagnosis of NLE in a baby does not predict that the mother will progress to systemic autoimmune disease [23]. Mother continues to possess these antibodies and may develop clinical features over the next 10 years even if asymptomatic at the time of the baby's birth [24]. Therefore, it is recommended to the infants' families to have regular and precise heart monitoring not only in terms of rhythm and rate, but also for ventricular function and late-onset cardiomyopathy [25].

\section{Conclusion}

NLE is a rare disease the clinical manifestation classically involves congenital $\mathrm{CHB}$ in the fetus and/or typical skin rash recognizable at birth. Congenital heart block can be a manifestation of isolated atrial septal aneurysm. Stable neonates with ventricular rate greater than $55 / \mathrm{min}$ can be periodically monitored for resolution of ASA.

\section{References}

1. Friedman DM, Duncanson LJ, Glickstein J, Buyon JP (2003) A review of congenital heart block. Images Paediatr Cardiol 5(3): 36-48.

2. Claus R, Hickstein H, Kulz T, Lenschow U, Meiske D, Kotitschke A, et al. (2006) Identification and management of fetuses at risk for, or affected by, congenital heart block associated with autoantibodies to SSA (Ro), SSB (La), or a HsEg5-like autoantigen. Rheumatol Int 26(10): 886-895.

3. Jaeggi E, Laskin C, Hamilton R, Silverman E (2010) The importance of maternal anti-Ro/SSA antibodies as prognostic markers of the development of cardiac neonatal lupus erythematosus: a prospective study of 186 antibody-exposed fetuses and infants. J Am Coll Cardiol 55(24): 2778-2784

4. Costedoat-Chalumeau N, Amoura Z, Lupoglazoff JM, Huong DL, Denjoy I, Vauthier D, et al. (2004) Outcome of pregnancies in patients with anti-SSA/Ro antibodies: a study of 165 pregnancies, with special focus on electrocardiographic variations in the children and comparison with a control group. Arthritis Rheum 50(10): 3187-3194.

5. Brucato A, Frassi M, Franceschini F, Cimaz R, Faden D, Pison MP, et al. (2001) A Risk of congenital complete heart block in newborns of mothers with anti-Ro/SSA antibodies detected by counterimmunoelectrophoresis: a prospective study of 100 women. Arthritis Rheum 44(8): 1832-1835.

6. Hutter D, Silverman ED, Jaeggi ET (2010) The benefits of transplacental treatment of isolated congenital complete heart block associated with maternal anti-Ro / SSA antibodies: a review. Scand J Immunol 72(3): 235-241.

7. Friedman DM, Kim MY, Copel JA, Davis C, Phoon CK, Glickstein JS, et al. (2008) Utility of cardiac monitoring in fetuses at risk for congenital heart block: the PR Interval and Dexamethasone Evaluation (PRIDE) prospective study. Circulation 117(4): 485-493.

8. Ayed K, Gorgi Y, Sfar I, Khrouf M (2004) Congenital heart block associated with maternal anti SSA/SSB antibodies: a report of four cases. Pathol Biol (Paris) 52(3): 138-147.

9. Jaeggi ET, Hamilton RM, Silverman ED, Zamora SA, Hornberger LK (2002) Outcome of children with fetal, neonatal or childhood diagnosis of isolated congenital atrioventricular block. A single institution's experience of 30 years. J Am Coll Cardiol 39(1): 130-137.

10. Moak JP, Barron KS, Hougen TJ, Wiles HB, Balaji S, Sreeram N, et al. (2001) Congenital heart block: development of late-onset cardiomyopathy, a previously underappreciated sequela. J Am Coll Cardiol 37(1): 238-242.

11. Reed JH, Sim S, Wolin SL, Clancy RM, Buyon JP (2013) Ro60 requires Y3 RNA for cell surface exposure and inflammation associated with cardiac manifestations of neonatal lupus. J Immunol 191: 110-116.

12. Ambrosi A, Dzikaite V, Park J, Strandberg L, Kuchroo VK, Herlenius E, et al. (2012) Anti-Ro52 monoclonal antibodies specific for amino acid 200-239, but not other Ro52 epitopes, induce congenital heart block in a rat model. Ann Rheum Dis 71: 448-454.

13. Spence D, Hornberger L, Hamilton R, Silverman ED (2006) Increased risk of complete congenital heart block in infants born to women with hypothyroidism and anti-Ro and/or anti-La antibodies. J Rheumatol 33: $167-170$.

14. Stevens AM, Hermes HM, Rutledge JC, Buyon JP, Nelson JL (2003) Myocardial-tissue-specific phenotype of maternal microchimerism in neonatal lupus congenital heart block. Lancet 362: 1617-1623.

15. Alvarez D, Briassouli P, Clancy RM, Zavadil J, Reed JH, Abellar RG, et al. (2011) A novel role of endothelin-1 in linking toll-like receptor 7-mediated inflammation to fibrosis in congenital heart block. J Biol Chem 286: 30444-30454.

16. Clancy RM, Marion MC, Kaufman KM, Ramos PS, Adler A; Harley JB, et al. (2010) Identification of candidate loci at 6p21 and 21q22 in a genome-wide association study of cardiac manifestations of neonatal lupus. Arthritis Rheum 62: 3415-3424.

17. Neiman AR, Lee LA, Weston WL, Buyon JP (2000) Cutaneous manifestations of neonatal lupus without heart block: Characteristics of mothers and children enrolled in a national registry. J Pediatr 137(5): 674-80.

18. Inzinger M, Salmhofer W, Binder B (2012) Neonatal lupus erythematosus and its clinical variability. J Dtsch Dermatol Ges 10: 407-411.

19. Peñate Y, Guillermo N, Rodríguez J, Hernández-Machín B, Montenegro T, Afonso JL, et al. (2009) Histopathologic characteristics of neonatal cutaneous lupus erythematosus: Description of five cases and literature review. J Cutan Pathol 36: 660-667.

20. Buyon JP, Hiebert R, Copel J, Craft J, Friedman D, Katholi M, et al. (1998) Autoimmune-associated congenital heart block: Demographics, mortality, morbidity and recurrence rates obtained from a national neonatal lupus registry. J Am Coll Cardiol 31(7): 1658-1666.

21. Moak JP, Barron KS, Hougen TJ, Wiles HB, Balaji S, Sreeram N, et al. (2001) Congenital heart block: Development of late-onset cardiomyopathy, a previously underappreciated sequela. J AmColl Cardiol 37: 238-242.

22. Llanos C, Friedman DM, Saxena A, Izmirly PM, Tseng CE, Dische R, et al. (2012) Anatomical and pathological findings in hearts from fetuses and infants with cardiac manifestations of neonatal lupus. Rheumatology (Oxford) 51: 1086-1092.

23. Cimaz R, Stramba-Badiale M, Brucato A, Catelli L, Panzeri P, Meroni PL (2000) QT interval prolongation in asymptomatic anti-SSA/ Ro-positive infants without congenital heart block. Arthritis Rheum 2000; 43:1049-53.

24. Kanagasegar S, Cimaz R, Kurien BT, Brucato A, Scofield RH (2002) Neonatal lupus manifests as isolated neutropenia and mildly abnormal liver functions. J Rheumatol 29: 187-191.

25. Boros CA, Spence D, Blaser S, Silverman ED (2007) Hydrocephalus and macrocephaly: New manifestations of neonatal lupus erythematosus. Arthritis Rheum 57(2): 261-266. 


\section{Your next submission with Juniper Publishers} will reach you the below assets

- Quality Editorial service

- Swift Peer Review

- Reprints availability

- E-prints Service

- Manuscript Podcast for convenient understanding

- Global attainment for your research

- Manuscript accessibility in different formats

( Pdf, E-pub, Full Text, Audio)

- Unceasing customer service

Track the below URL for one-step submission https://juniperpublishers.com/online-submission.php 